\title{
MICRO-CREDIT AND POVERTY REDUCTION: A CASE OF BANGLADESH
}

\author{
Mohummed Shofi Ullah Mazumder, Lu Wencong*
}

\begin{abstract}
:
Bangladesh is a pioneer and home of conceptualizing micro-credit program. It has undertaken a number of such programs to reduce poverty and bring about socio-economic changes in the rural community. The main purpose of this paper is to give an overview about access to micro-credit for rural poor and its impact on their poverty situation and relevant factors related to income of the micro-credit recipients. Data was collected in two phases from the same respondents (April 2009 and April 2010) using a face-to-face interview schedule from a sample of 360 micro-credit recipients. Additionally, another set of 60 non-credit beneficiary respondents was also taken as a control group to compare the consequences of the program. Major findings reveal that positive impact was found on income, assets endowment, standard of living and poverty reduction. Utilization of credit appears to be major factor for credit recipients raising income compared to their control group. This shows that micro-credit tends to be an important factor to have an impact on household income which minimizes the poverty situation to a reasonable extent.
\end{abstract}

Keywords: micro-credit, socio-economic impact, poverty alleviation.

JEL Classification: H81

\section{Introduction}

Poverty is a complex phenomenon and its causes and effects are more complex process (Ismail, 2000). In every developing nation, the ongoing crucial issue is socio-economic development and poverty alleviation. As a developing country, Bangladesh has been putting vigorous attempts towards achieving this goal. Micro-credit is considered as one of the vital tools for poverty alleviation in Bangladesh (The Role of Micro-Credit in Poverty Alleviation, 2009).

Micro-credit, according to Otero (1999), is considered to be "the provision of financial services to low-income poor and very poor self-employed people". These financial services generally include savings and credit, but can also include other services such as insurance and payment services as revealed by Ledgerwood (1999). On the other hand,

* M. Shofi Ullah Mazumder, Dept. of Agricultural Economics and Management, Zi-Jin-Gang Campus, Zhejiang University, Hangzhou - 310085, China; Dept of AEIS, Sher-e-Bangla Agricultural University, Sher-e-Bangla Nagar, Dhaka-1207, Bangladesh (shofi_keron@yahoo.com). Corresponding author: Lu Wencong, Dept. of Agricultural Economics and Management, Zi-Jin-Gang Campus, Zhejiang University, Hangzhou - 310085, China (wenclu@zju.edu.cn). 
Schreiner and Colombet (2001) define micro-credit as an attempt to improve access to small deposits and small loans for poor households neglected by banks. This implies that micro-credit involves the poor people in getting financial services like savings, loans, insurance etc. enabling them to lead a descent living in both urban and rural settings who are unable to obtain such services from the formal financial sector.

According to Human Development Index (HDI), Bangladesh ranked 140 out of 177 countries in the world in 2007 (UNDP, 2007). Per capita annual income was USD520 in 2006-07 (Socio-Economic Indicator of Bangladesh, 2007). At present about 40\% people live in below poverty line in Bangladesh (BBS, 2007). Three years after liberation war in 1974, there was a famine in Bangladesh which made majority of its people near starvation. In the late 1970 s, to overcome and improve this situation Nobel laureate Dr. Muhammed Yunus, a pioneer of micro-credit in Bangladesh, initiated a micro-credit program, primarily targeting the poorest of the society, especially for women. It is now a widespread program in Bangladesh and a household name. Micro-credit thus becomes a revolutionary concept in Bangladesh from the eighties onward (The Bangladesh Development Studies, 2004). From the last three decades it emerges a unique innovation of credit delivery system as an income generating activities of Bangladeshi poor. At present, according to NGO Affairs Bureau, about 2,116 NGOs have been operating micro-credit program in Bangladesh and number of clients increased sharply (Assessment of MicroCredit Program in Bangladesh, 2010). Mentioned all of NGOs along with 13 Ministries/ Divisions of the Bangladesh Government covered about 23 per cent households around the world (World Bank, 2005).

"It is very difficult for the poor to get small working capital from formal banking system for various reasons. Money makes money and when you got a little, it is often easy to get more. The great hardship is to get the little" (Adam Smith, 1976). Rodenbeck (1998) observed that it is an emerging agenda for development in the Middle East and North Africa to have access to credit. In Bangladesh, government sector served about 10 million poor and NGOs sector served 20 million poor (Assessment of Micro-Credit Program in Bangladesh, 2010). An increasing trend was observed in outstanding loans over the period 2006 to 2009 (Bangladesh Microfinance Statistics 2009). Both GOs and NGOs together in Bangladesh, total loan outstanding is around Tk 200 billion and savings Tk140 billion. In spite of such fact, the unmet demand of micro-credit remains enormously unattended although Bangladesh government and NGOs have disbursed huge amount of money so far since micro-credit ordained to poverty alleviation (Assessment of MicroCredit Program in Bangladesh, 2010).

The average loan size per borrower is about USD 60 and the typical size of loan per person ranges from USD46 to USD 80 only. In case of RDRS, it was less than average amount (USD40 in 1998, USD25 in 1999 and USD30 in 2000), respectively. The lending rates of micro-credit among NGOs have been rising in recent years by changing the method of interest calculation and incorporating service charges. The PKSF study provides current data about the interest rates charged by various GOB programs. It varies from $10 \%$ to $20 \%$ at varying circumstances. They manipulate such rate of interest 
artificially and nowhere they allow borrowers to meet the full costs of their operations (especially given their poor recovery of loans, hardly better than $90 \%$ and sometimes less than $80 \%$ ). In Bangladesh, $80 \%$ of micro-credit NGOs charge annual interest rates of $11-15 \%$ (on a flat basis), RDRS is one of them, and $14 \%$ of them charge $16-20 \%$ (flat). With regard to savings, 53\% NGOs including RDRS provide annual interest on savings of 6-7\% while $22 \%$ provides interest rates of $8-10 \%$ (Assessment of MicroCredit Program in Bangladesh, 2010).

Since the 1970s, especially during the new wave of microfinance in the 1990s, microcredit has come to be seen as an important development policy and a poverty reduction tool. Some suggest (Littlefield et al., 2003; World Savings Bank Institute, 2010) that micro-credit is a key tool to achieve the Millennium Development Goals (MDGs). It is the most sensational anti-poverty tool for the poorest, especially for women (The Microcredit Summit 1997), because only less than 10\% of the adult populations in many Asian and African countries have bank account. The success of micro-credit has captured the interest of many researchers in broad areas, for example, in the field of women's empowerment (Hashemi and Schuler, 1996; Sen, 1997; Goetz, Marie \& Sengupta, 1996), sustainability and outreach, (McNamara and Morse, 1998; Sharma and Zeller, 1999), group based lending, (Ghatak, 1999; Stiglitz, 1990; Varian, 1990) and poverty alleviation. The assumption is that if one gives more micro-credit to poor people, poverty will be reduced, but evidence regarding such impact is challenging and controversial. Based on the success stories (Montgomery et al. 1996) it is assumed that micro-credit is pioneer in improving standard of living and well-being of the borrowers by way of their level of consumption. Questions regarding impact of micro-credit on the welfare and income of the poor have therefore been raised many times (Copestake, 2002; Khandker, 2003; Rogaly, 1996). Despite various studies, the effectiveness and impact of microcredit programs on the poor is still highly in question' (Westover, 2008). Roodman and Morduch (2009) reviewed study on micro-credit in Bangladesh, and concluded that 30 years in the micro-credit movement we have little solid evidence that it has improved the lives of clients in measurable terms.

All these studies, however, did not find a strong causal link between access to microcredit and poverty reduction for the poor. At the moment, we neither have very strong evidence that this particular proposition is true, nor we can put out public relations material that fudges the issue or suggest that we do have such evidence. In this situation, researchers attempted to conduct related study for getting specific findings with extended clarification. The aim of this paper is to provide an overview pertaining to access of micro-credit to the rural poor and its impact on their poverty level with an assessment of their credit delivery utilization efficiency.

The remainder of the paper is structured as follows: The first section presents essence of micro-credit as introduction. The second section explains the methodology used and data collected at the field level. The third major part of the paper demonstrates and discusses the results. The key points of the research findings are pointed out in the fourth section as conclusion. 


\section{Materials and Methods}

The principal method employed for this study was a field survey using a semi-structured interview schedule. The study was conducted in six villages of three unions of Gangachhara Upazila of Rangpur district under the RDRS commanding area in the northwest region of Bangladesh. The study villages and unions were selected based on availability of credit recipient people. Only the micro-credit recipients of the study area were considered as population for the study. All micro-credit respondents were female according to RDRS credit distribution criteria. The whole set of individuals i.e. microcredit recipients under the study were estimated to be around 940. Among them, 360 respondents were chosen as sampling frame using Kothari formula (2004).

Credit respondents were randomly selected using proportionate random sampling procedure considering each of the village population. Additionally, 60 non-credit respondents taking 10 from each village were also selected and interviewed as a control group for comparative analysis on impact of the program. A reserve list was maintained to fill in the gap in case any respondent in original list is found missing.

Data was collected in two phases from the same respondents through face-to-face interview. At the first time (April/2009), data was gathered from those who did not receive any credit from any organization in their lifetime. So they are the first time creditrecipients. In the second time (April/2010), data was collected from same respondents after one year of their engagement with credit program when they already paid all credit installments (46 installments in 46 weeks) against their received money. Simultaneously, data was also collected from the control group-respondents (who did not receive any such micro-credit from any credit supporting institution). Similar socio-economic backgrounds were also considered while selecting the control group.

Along with semi-structured interview schedule, a checklist was also used to collect qualitative data that helped justify the data authenticity. Moreover, few focus group discussions (FGDs) were organized as another method and technique in order to cross verify the collected information and data through questionnaire survey. All the filled-in schedules were edited and coded before processing by computer software.

Impact of the credit program was assessed by comparing the situation of change in income, assets development, level of living, lifestyle patterns and poverty status before and after engagement with credit program. Change in living standard is a broad term and it was measured in terms of change in sources of drinking water, hygienic and sanitation practices, medicare, annual expenditure on clothing and electricity consumption. Different statistical tests (Chi-square, F-test) were used to analyse the association and extent of contribution within the variables. In order to assess the factors related to income, education and other variables of the borrowers, multiple regression analysis was performed. The model used for this analysis can be explained as follows:

$$
\mathrm{Y}=\mathrm{a}+\mathrm{b}_{1} \mathrm{x}_{1}+\mathrm{b}_{2} \mathrm{x}_{2}+\mathrm{b}_{3} \mathrm{x}_{3}+\mathrm{b}_{4} \mathrm{x}_{4}+\mathrm{b}_{5} \mathrm{x}_{5}+\mathrm{e}
$$


Where, $\mathrm{Y}$ is the total income of the credit respondents after joining with credit program;

$\mathrm{x}_{1}$ is loan amount received by the respondents;

$\mathrm{x}_{2}$ is income through utilization;

$\mathrm{x}_{3}$ is number of earning members;

$\mathrm{x}_{4}$ is year(s) of schooling of the respondents;

$\mathrm{x}_{5}$ is household size of the respondents;

$\mathrm{b}_{1}, \mathrm{~b}_{2}, \mathrm{~b}_{3}, \mathrm{~b}_{4}$ and $\mathrm{b}_{5}$ are regression coefficients of the corresponding independent variables and "e" is random error, which is normally and independently distributed with zero (0) mean and constant variance.

Data was processed through SPSS computer software. Statistical measures like multiple regression analysis, Chi-square test, etc. were performed using same computer software. Data was presented in tables and graphs where applicable.

\section{Results and Discussion}

\section{Impact of micro-credit program on poverty reduction}

Impact of micro-credit program on poverty reduction was measured by considering four dimensions: change in income, change in farm and household assets, change in living standard and change in poverty situations.

Change in income: Micro-credit respondents earned income by undertaking different productive activities utilizing credit received from RDRS. Main sources of income were raising crops, animal, fisheries, business and other livelihood activities. Change score was computed by considering changes of productive activities that were converted to a value in taka (USD1= BDT75). On the basis of level of income per month, the respondents (credit and control group) were classified into three different categories, such as low income (up to Tk 5,000), medium income (Tk5,001 to Tk 12,000) and high income ( $T k 12,001$ and above).

Distribution of micro-credit respondents according to their change in income per month indicates that before taking loan majority of the respondents $(63.3 \%)$ were in low income group, nearly one-fourth of them (26.7\%) in medium income and the rest $10 \%$ in high income groups. But after joining the micro-credit program, medium income group increased reasonably ( $45.6 \%$ from $26.7 \%$ ) and at the same time low income group decreased drastically (40.0\% from 63.3\%). A few respondents (14.4\%) also improved their income with high amount. Only one respondent was economically loser. It may be that this respondent might have faced some unexpected debacles or disasters that hinder her level of income. Besides, few of them (11.1\%) had no change in their income. It could be they might have consumed part of the loan for personal uses rather than investment in income generating activities. Similar results also found by Siddique et 
al. (2002). Barnes et al. (1999) who conducted a study in Zimbabwe and concluded some controversial findings. They found that nearly half of the new client and non-client households had a monthly income of less than $Z \$ 2,000$, compared with about one-fifth of the repeat client households. In contrast, half of the repeat clients had an estimated monthly household income of $\mathrm{Z} \$ 4,000$ or more.

Figure 1. Distribution of Micro-Credit Respondents and Control Group Respondents
According to Their Change in Income per Month

nefore Taking Loan

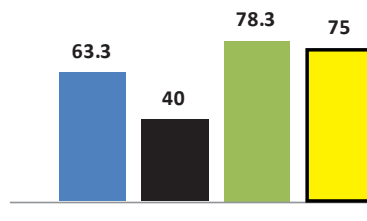

Low (Up to $5000 \mathrm{Tk}$.)
- After Taking Loan

- In April, 2009
口 In April, 2010

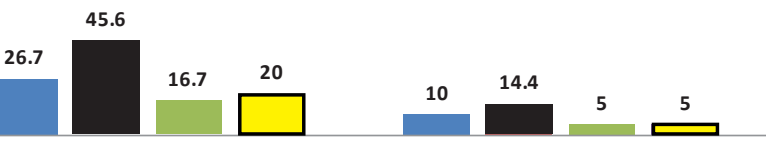

Medium (5001- 12000 Tk.)

High (12001 and above Tk.)

Note: Chi-square value $128.68^{* \star} .{ }^{* *}$ indicates significant at $1 \%$ level.

But in respect of control group members, no considerable change took place in their income. It may be due to unavailability of money for initial investment or perhaps misused the workable time.

The Chi-square value implies that there is a significant relation between respondents' increase of income and their involvement in micro-credit program.

Change in farm and household assets: Household assets include furniture, farm implements, poultry, livestock and electrical goods. Change scores were computed by considering change in number of different assets. Distribution of number of credit respondents according to their farm and household assets shows that almost all of them increased their assets after joining the credit program (sofa set from 0 to $2 \mathrm{pcs}$, bed from 92pcs to $124 \mathrm{pcs}$, mobile phone from 0 to $24 \mathrm{pcs}$, electric fan from $40 \mathrm{pcs}$ to $88 \mathrm{pcs}$, hen/ duck from $256 \mathrm{pcs}$ to $328 \mathrm{pcs}$, goat from $44 \mathrm{pcs}$ to $128 \mathrm{pcs}$, cow from $36 \mathrm{pcs}$ to $100 \mathrm{pcs}$, radio from 12 pcs to $36 \mathrm{pcs}$ and television from 0 to $40 \mathrm{pcs}$ ).

It may be after their involvement with credit program, they invested money in different income generating activities and uplifted their economic condition. Similar findings also identified by Haque and Masahiro (2009) by conducting "NGOs-MFIs MembersImpact Assessment Survey". They found that about $98.33 \%$ borrowers had some kind of physical assets while the rest could not increase due to some unexplained reasons.

Similarly, in case of control group members, there was no considerable change in respect of their increase in household assets during the study periods (from April 2009 to April 2010). It implies that micro-credit is the essential instrument that plays a vital role for poverty reduction. 
Figure 2.

Distribution of Number of Assets of Credit Respondents and Control Group Members According to Their Farm \& Household Assets

$*$ No. of Assets Before Taking loan

$\square$ No. of Assets of Control Group Members In April, 2009

- No. of Assets After Taking Loan

No. of Assets of Control Group Members In April, 2010

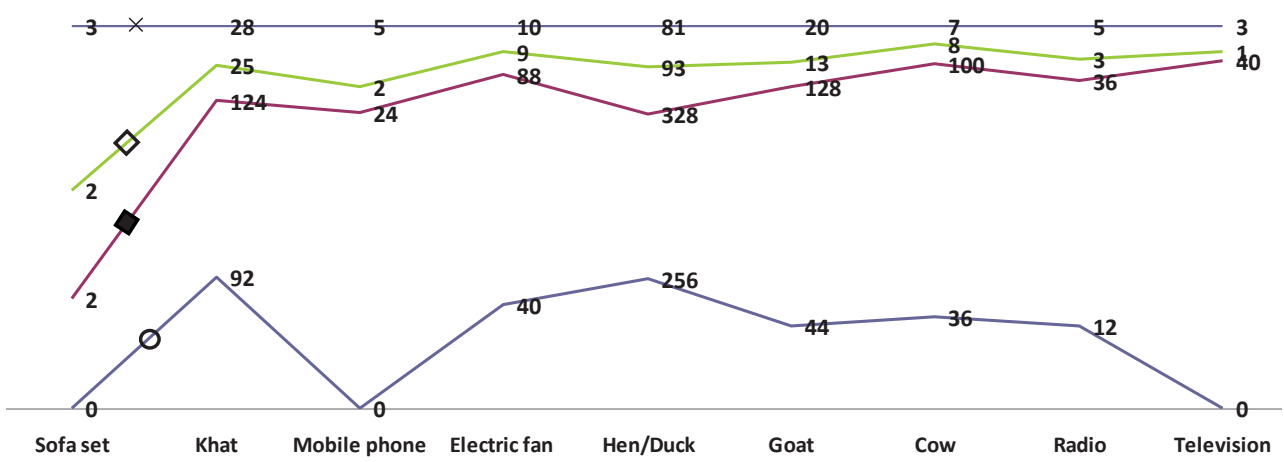

Change in standard of living: Standard of living includes sources of drinking water, toilet condition, medicare, number of clothing per year and electricity consumption level. Change scores were computed by considering changes in above-mentioned sectors.

Change in sources of drinking water was considered by number of users before and after joining the credit program. It indicates that all respondents (100\%) used tube-well to meet their daily water requirement after their involvement in credit program whereas before joining it was $93.4 \%$ and the rest $6.6 \%$ used either river or pond water.

Figure 3a.

Distribution of Credit Respondents and Control Group Members According to Their Change in Sources of Drinking Water

Tube-well water

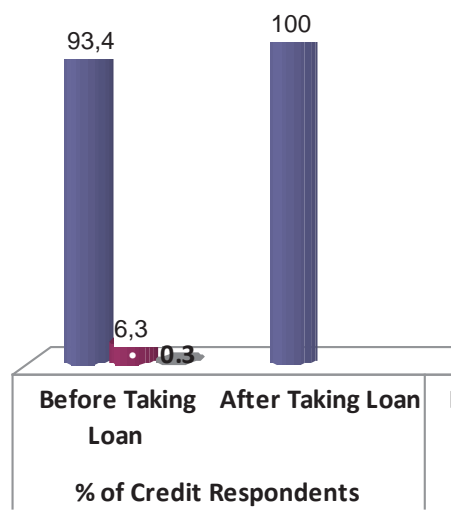

- Boiled pond water

Pond water 
A significant change followed within the control group members in respect of their using drinking water between the study periods (from April 2009 to April 2010). Financial solvency of the credit respondents influenced to fix and use tube-wells in the study area. The increasing trend of fixing and using tube-well also influenced the control group members since they could consume it from other owner's tube-well without spending money (Figure 3a). This indicates that credit respondents' health consciousness has substantially improved.

Change in use of latrine was considered by number of different types of latrine users before and after joining the credit program. It shows that after involvement with credit activities, percentage of pucca (metaled latrine) and ring slab (pit) users increased from 44.5 to $82.3 \%$. It also indicates that after involvement in credit program, percentage of kutcha (without ring slab and only earthen) and open space users decreased from 55.5 to $17.7 \%$. Sanitation behaviour has changed within the credit respondents. This may be due to their involvement with credit program. It also enhanced respondents' financial ability and became more aware of health and sanitation practices by taking lesson from NGO workers.

Figure 3b.

Distribution of Credit Respondents and Control Group Members According to Their Change in Type of Latrine

\% of Credit Respondents Before Taking Loan

\% of Control Group Members In April, 2009
\% of Credit Respondents Afte

$\square \%$ of Control Group Members

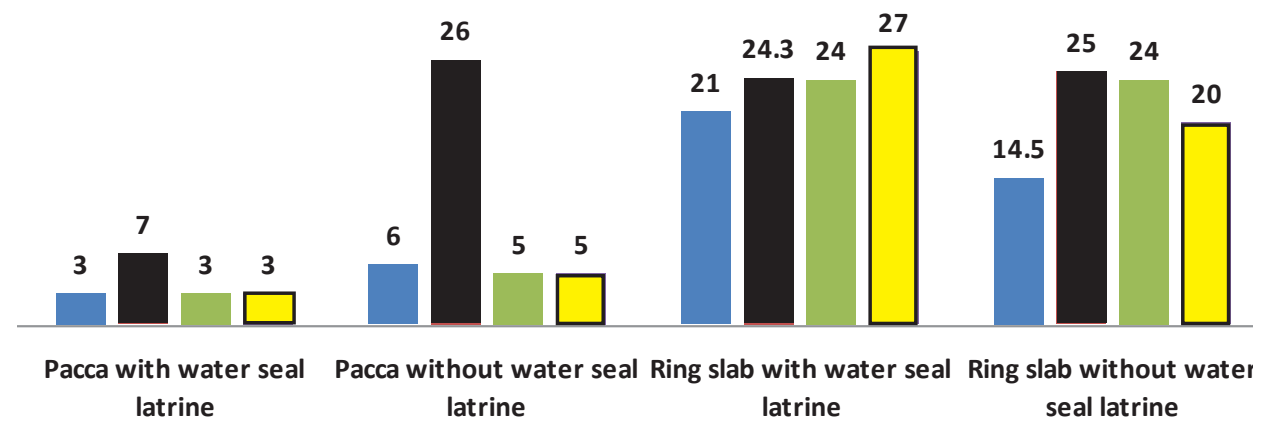

On the contrary, the control group members did not have any change in their sanitation behaviour (Figure 3b).

Change in medicare was considered by number of service receivers from several qualified health service providers before and after joining the credit program. It shows that after joining with credit program, credit respondents' medical treatments increased to $77.8 \%, 15.6 \%, 4.4 \%, 2.2 \%$ and $0 \%$ respectively in connection with trained doctor, MBBS doctor, homeopath, pir/ fakir (holy man/spiritual guide) and quack (a pretender 
to medical skill). Before joining, the corresponding figures were $66.7 \%, 11.1 \%, 17.8 \%$, $4.4 \%$ and $0 \%$, respectively (Figure $3 \mathrm{c}$ ). It may be that increasing trend of daily earning ability of the credit recipients and their self-awareness was influenced by credit officials. Similar findings were found by Nelly et al. (1999) from the study of impact of microcredit in Bolivia that provided to women groups. They found that micro-credit increased income and savings, improved health/nutrition knowledge and practice, as it has empowered women.

Figure 3c.

Distribution of Credit Respondents and Control Group Members According to Their Change in Medicare

$\square \%$ of Credit Respondents Before Taking Loan

$\square \%$ of Control Group Members In April, 2009

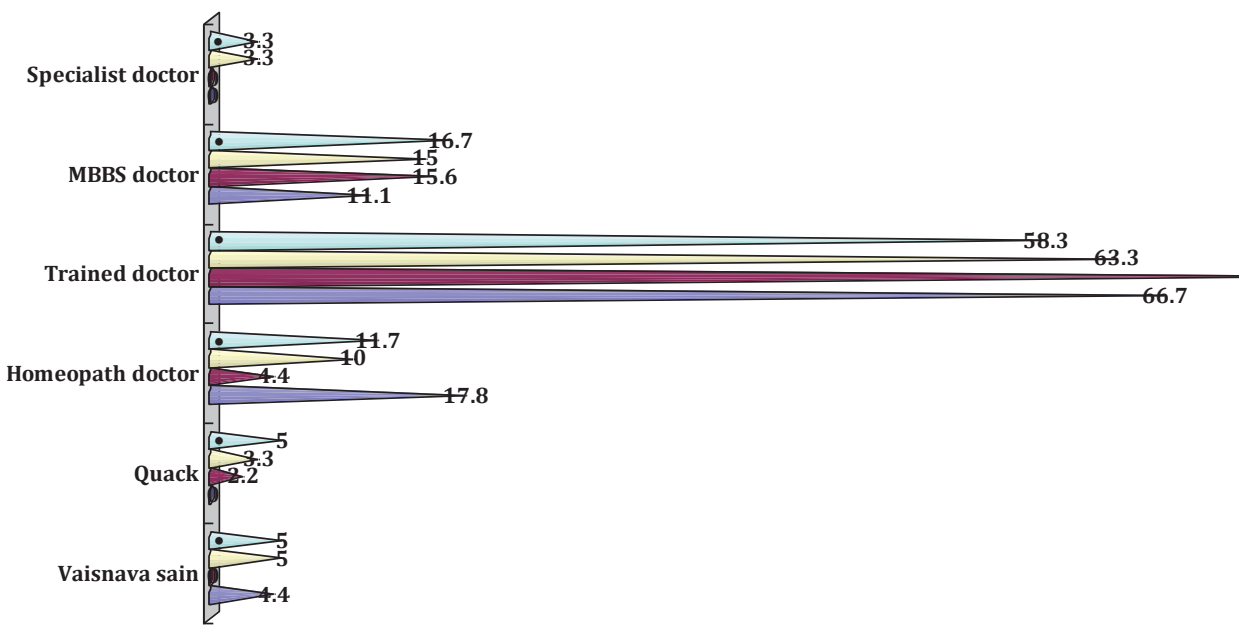

But there were no considerable medicare change in respect of control group members. It implies that there is a positive influence of micro-credit on enjoying proper medicare facilities in case of micro-credit recipients.

Change in number of cloth was determined in number of clothes used by the credit recipients per year before and after joining the credit program. It indicates that after involvement with credit program, the recipients used increasing number of clothes every year. The majority of the respondents $(60 \%)$ used three (3) to four (4) clothes per year compared to $46.7 \%$ in the previous years. Before involvement, $53.3 \%$ of the respondents used only two (2) clothes per year, but after involvement, two clothes user was decreased up to $8.9 \%$ and more than four clothes users increased from zero (0) to $31.1 \%$. It implies that after involvement with credit program, respondents improved their standard of living using more and better clothing thereby improving their economic ability. 
Figure 3d.

Change in Number of Cloth Used by the Credit Respondents and Control
Group Members per Year

$\square$ cloths users (year)

口-4 cloths users (year)

5 or more cloths users (year)

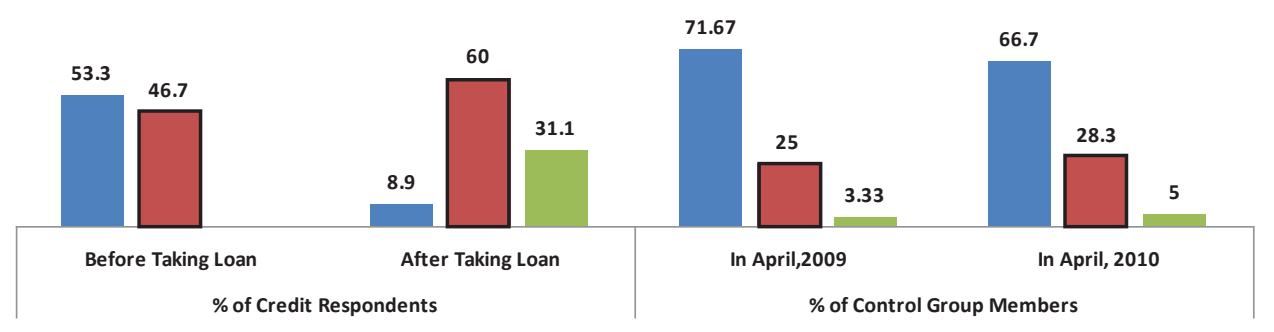

Nelly et al. (1998) conducted a study on "Impact of Credit with Education on Mothers and Their Young Children's Nutrition Program in Ghana" and found similar findings with significant differences across the groups in change of household expenditures on food, clothing, medicine, school expenses, house repairs or business assets.

In case of non-credit group members, no considerable change took place on yearly expenditure on clothing (Figure 3d).

Change in electricity consumption was determined by frequent use of electricity facilities before and after joining the credit program. It appears that before involvement with credit program, 55.6\% respondents were unable to connect with electricity facilities. But after involvement, electricity non-consumers percentage decreased to $37.8 \%$. It indicates that economic solvency may influence to consume more electricity facilities compared to previous situation. Similar findings were identified by Rahman et al. (2003) in their study "Microcredit Programs and Consumption Behaviour: Are the Borrowers Better Off? Evidence from Bangladesh" in 2003 and found that borrowers as a whole were better off in terms of consumption of all food items and some non-food items such as fuel and electricity.

In case of control group members the electricity consumption increased a little higher than one year before, but the cause was nonspecific (Figure 3e).

It seems that there is a substantial positive impact between micro-credit and standard of living in all aspects. Adam (2010) got similar findings and found that there has been a positive relationship between financial expenses and standard of living. 
Figure 3e.

Distribution of Credit Respondents and Control Group Respondents Accrding to Their Change in Electricity Connection

- Having with electric support W Without having electric support

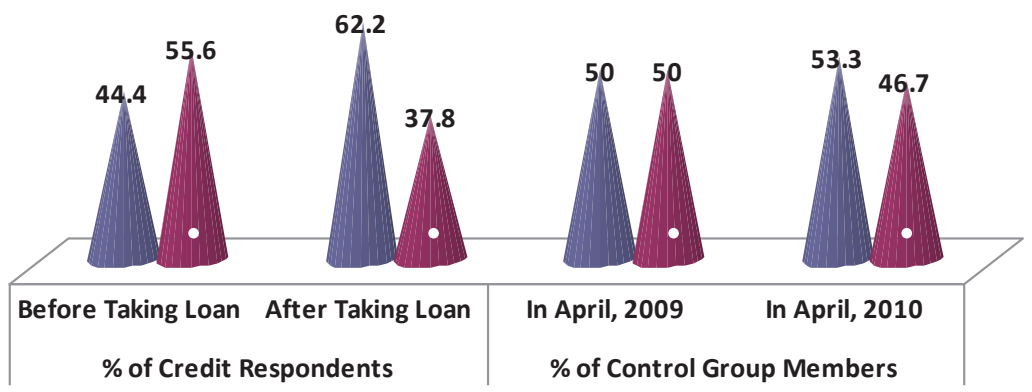

\section{Change in poverty situation:}

Distribution of credit and non-credit respondents according to their poverty situation indicates the nature of prevailing poverty situation. Traditionally, poverty is conceptualized in terms of income and expenditure ability. The poverty situation was classified into five categories; these are: non poor, tomorrow's poor, absolute poor, hard-core poor and ultra poor (Extreme Poverty Policies of Donors in Bangladesh: An Overview, 2007). Poverty situation reveals that after involvement with micro-credit program percentage of non-poor increased from 2.2 to $13.3 \%$ and tomorrow's poor increased from 13.3 to $46.7 \%$. Figure 5 also shows that after involvement with micro-credit program the percentage of absolute poor, hard-core poor and ultra poor were in decreasing trend.

Figure 4.

Distribution of Micro-Credit Respondents and Control Group Members According to Their Change in Poverty Situation

\% of Credit Respondents Before Taking Loan

\% of Control Group Members In April, 2009
\% of Credit Respondents After Taking Loan

口\% of Control Group Members In April, 2010

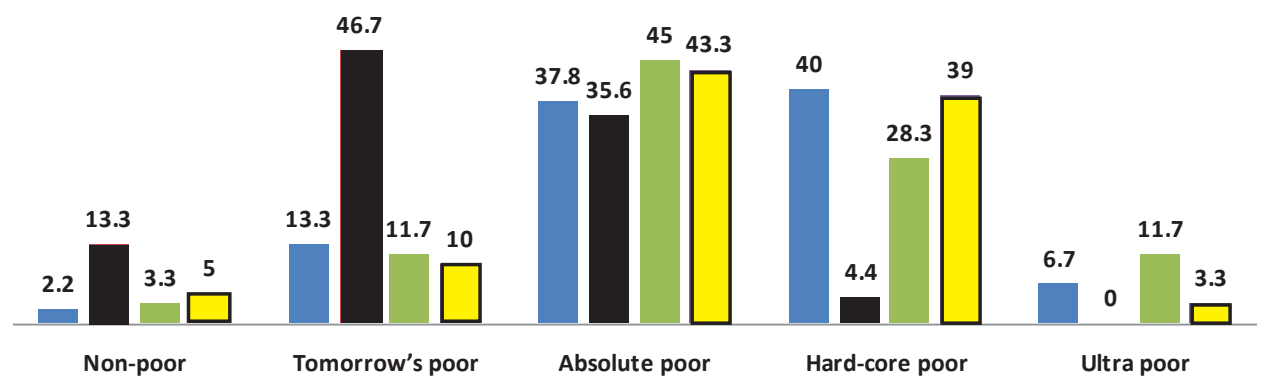

Note: Chi-square value $221.02^{\star *}{ }^{* *}$ indicates significant at $1 \%$ level of significance. 
The situation seems to be reasonable because after involvement with credit program the respondents utilized their credit and earned more money compared to previous situation. Similar study conducted by Haque and Masahiro (2009) showed contrary results that majority of the respondents (71.41\%) felt that there had been no change in their lifestyle while $23.52 \%$ of the borrowers previously wealthier felt that status of livelihoods had been improved. A few clients (5.06\%) reported that they had been adversely affected by their involvement in NGO-MFIs. Loss of property for being defaulters and the burden of indebtedness were frequently cited as the major reasons for the negative effect. In respect of control group members, there had no significant change in their poverty situation.

Chi-square value shows that there is a significant association between the acceptance of micro-credit and reduction of poverty. This implies that micro-credit has a positive impact on poverty reduction. If it is considered that non-poor and tomorrows poor as above poverty line and absolute poor, hardcore poor and ultra poor as below poverty line, the households who live in below the poverty line decreased from about 85 to $40 \%$ after involvement with micro-credit. This implies that after involvement with micro-credit program, more than one half of the households graduated from below poverty line to above poverty line.

\section{Relationship between access to micro-credit and poverty reduction:}

Data contained in Table 1 are the basis for testing the research hypothesis which shows that micro-credit has a significant impact on poverty reduction.

Table 1

Associate Relation between Access to Credit and Poverty Category

\begin{tabular}{|l|c|c|c|c|}
\hline \multirow{2}{*}{ Poverty category } & \multicolumn{2}{|c|}{ Access to credit } & \multirow{2}{*}{ d.f. } & \multirow{2}{*}{ Chi-squarer value } \\
\cline { 2 - 3 } & Before & After & & \\
\hline Poor & $312(86.7 \%)$ & $144(40.0 \%)$ & \multirow{2}{*}{8} & \multirow{2}{*}{$84.40^{* *}$} \\
\hline Non-poor & $48(13.3 \%)$ & $216(60.0 \%)$ & & \\
\hline Total & 360 & 360 & & \\
\hline
\end{tabular}

** Indicates significant at $1 \%$ level of significance. Critical Value of Chi-square $=6.63$.

This also indicates that before involvement with credit program the poor were $86.7 \%$ and thereafter decreased to $40.0 \%$. Accordingly, before involving with micro-credit, the non-poor were $13.3 \%$ and then increased to $60.0 \%$. This implies that incidence of poverty decreased through access to credit.

The chi-square value is significant at $1 \%$ level of significance. It can be concluded that access to micro-credit has a significant relationship with the reduction of poverty. This finding validates the hypothesis that micro-credit has a significant impact on poverty reduction. 
In order to assess the factors related to income of the borrowers, multiple regression analysis was used.

Table 2

Multiple Regression Coefficients of Contributing Factors on Total Income after Joining Micro-Credit Program

\begin{tabular}{|c|c|c|c|c|}
\hline $\begin{array}{l}\text { Dependent } \\
\text { variable }\end{array}$ & Independent variables & $\begin{array}{l}\text { Regression } \\
\text { coefficient }\end{array}$ & Adjusted $\mathbf{R}^{2}$ & F-value \\
\hline \multirow{5}{*}{$\begin{array}{l}\text { Total income } \\
\text { after joining } \\
\text { credit program }\end{array}$} & Loan amount received & $0.055^{*}$ & \multirow{5}{*}{0.18} & \multirow{5}{*}{$2.917^{*}$} \\
\hline & Income through utilization of credit & $0.008^{* *}$ & & \\
\hline & Number of earning member & $0.033^{*}$ & & \\
\hline & Years of schooling & $0.035^{*}$ & & \\
\hline & Household size of the respondent & 0.102 & & \\
\hline
\end{tabular}

${ }^{*}$ and ${ }^{* *}$ indicate significant at $5 \%$ and $1 \%$ level of significance respectively. Critical value of $F=2.2141$.

Table 2 shows that there is a significant contribution in loan amount received, income through utilization of credit, number of earning member and years of schooling after joining the micro-credit program. Among these, income through utilization of credit is the most important contributing factor (significant at $1 \%$ level of significance), whereas the coefficients of other factors are significant at $5 \%$ level of significance. Jehangir et al. (2002) conducted similar study who found that there was a positive and significant relationship between the amount of credit and the total income.

\section{Conclusion}

It is generally perceived that micro-credit program helps to improve socio-economic status of the rural women in Bangladesh. Accordingly, this program under RDRS commanding area increased the economic status of the credit recipients and also increased the farm and household assets. The involvement in credit program had a positive impact on different dimensions of the participants' standard of living. Majority of the respondents appear to upscale their poverty situation by properly utilizing the credit received. This implies that there is a positive relationship between poverty reduction and access to micro-credit, i.e., after taking loan poverty level of the participants decreased significantly, whereas in respect of control group members, the poverty level remained almost unchanged. This suggests that efforts should be given to increase income earning through proper utilization of micro-credit and that appropriate monitoring system needs to be established by the micro-finance institute. 


\section{References}

Adam, A. M. (2010), "Financial Openness Induced Growth and Poverty Reduction." The International Journal of Applied Economics and Finance, 5: 75-86.

Assessment of Micro-Credit Program in Bangladesh. (2010), Retrieved from www.docstoc.com/.../ Assessment-of-Micro-Credit-Programme-in-Bangladesh.

Bangladesh Bureau of Statistics. (2007), Statistical Pocket Book. Statistics Division. Ministry of Planning. Government of Peoples Republic of Bangladesh. Dhaka. Retrieved from: www.bbs. gov.bd /Home.aspx.

Bangladesh Microfinance Statistics. (2009), Retrieved from_Institute of Microfinance (InM) and Credit and Development Forum (CDF). Available at http://www.inm.org.bd/statistics/2009/ Chapter\%202_Trends\%20and\%20Growth.pdf.

Barnes, C., Keogh, E. (1999), An Assessment of the Impact of Zambuko's Microenterprise Program in Zimbabwe: Baseline findings. Working Paper. Management Systems International (MSI). Retrieved from http://www.mip.org.

Copestake, J., Johnson, S., Wright, K. (2002), Impact Assessment of Micro-Finance: towards a New Protocol for Collection and Analysis of Qualitative Data (Working Paper No. 7). Brighton: Institute of Development Studies, University of Sussex.

Extreme Poverty Policies of Donors in Bangladesh: An Overview. (2007), Retrieved from http:// www.extreme-poverty.org/files/Shiree_Donor_Policy.pdf.

Ghatak, M. (1999), "Group Lending Local Information and Peer Selection." Journal of Development Economics, Vol. 60, 1999. pp. 27-50.

Goetz, A.-M., Sengupta, R. (1996), "Who Takes the Credit? Gender, Power, and Control over Loan Use in Rural Credit Programs in Bangladesh." World Development, Vol. 24, No. 1. pp. 45-63.

Haque, S., Masahiro, Y. (2009), "NGOs-MFls Members-impact Assessment Survey." International Journal of Business, Economics, Finance and Management Science, Vol. 1, No. 1, 2009.

Hashemi, S. M., Schuler, S. R. (1996), "Rural Credit Programs and Women's Empowerment in Bangladesh." World Development 24(4): pp. 635-653.

Ismail, S. (2000), Elimination of Poverty: Challenges and Islamic Strategies, Islamic Economic Studies, Vol. 8, No. 1, p.1.

Jehangir, W. A., Ashfaq, M., Ali, A., Sarwar, N. (2002), Use of Credit for Poverty Reduction by Small Farmers. Journal of Applied Science, pp. 2: 777-780.

Khandker, S. R. (2003), "Microfinance and Poverty: Evidence Using Panel Data from Bangladesh." (World Bank Policy Research Working Paper 2945). Washington DC: World Bank.

Kothari, C. R. (2004), Research Methodology: Methods and Techniques. India: Wishwa Prakashan.33.

Littlefield, E., Morduch, J., Mesbahuddin, S. H. (2003), "Is Microfinance an Effective Strategy to Reach the Millennium Development Goals?" CGAP Focus Note. Washington, DC: CGAP.

Ledgerwood, J. (1999), Microfinance Handbook: An Institutional and Financial Perspective. Washington: The World Bank.

McNamara, N., Morse, S. (1998), "Donors and Sustainability in the Provision of Financial Services in Nigeria." IDS Bulletin, Vol. 29, pp. 91-101.

Montgomery, R., Bhattacharya, D., Hulme, D. (1996), "Credit for the Poor in Bangladesh: The BRAC Rural Development Program and the Government Thana Resource Development and Employment Program." In Hulme, D., Mosley, P., Finance against Poverty, Vol. 1 and 2, Rutledge, London.

MkNelly, B., Dunford, Ch. (1999), "Impact of Credit with Education on Mothers and Their Young Children's Nutrition: CRECER Credit with Education Program in Bolivia." Freedom from Hunger Research Paper No. 5. Freedom from Hunger. Davis, CA. 
MkNelly, B., Stack. K. E. (1998), "Loan Size Growth and Sustainability in Village Banking Programs." Small Enterprise Development, 9 (2): pp. 4-16.

Otero, M. (1999), Microfinance and the Poor. Journal of International Development. Vol. 5, pp. 65-72.

Rahman, S., Mallik, G., Raja, P. N. (2003), "Micro-Credit Programs and Consumption Behavior: Are the Borrowers Better Off? Evidence from Bangladesh". P.1. Retrieved from https:// editorialexpress. com/cgi-bin/.../download.cgi?db...id.

Rodenbeck, M. (1998), "An Emerging Agenda for Development in the Middle East and North Africa." Retrieved from http://www.idrc.ca/books/focus/930/12rodenb.html.

Rogaly, B. (1996), "Micro-Finance Evangelism, Destitute Women and the Hard Selling of a New AntiPoverty Formula." Development in Practice 6 (2): pp. 100-112.

Roodman, D., Morduch, J. (2009), "The Impact of Micro-Credit on the Poor in Bangladesh: Revisiting the Evidence." (Working Paper No. 174). Washington DC: Centre for Global Development.

Schreiner, M., Colombet, H. H. (2001), "From Urban to Rural: Lessons for Microfinance from Argentina." Development Policy Review, 19(3), pp. 339-354.

Sen, G. (1997), "Empowerment as an Approach to Poverty." Human Development Report. pp. 96-97.

Sharma, M., Zeller, M. (1999), "Placement and Outreach of Group-Based Credit Organizations: The Cases of ASA, BRAC, and PROSHIKA in Bangladesh." World Development, Vol. 27, No. 12, pp. 2123-2136.

Siddiqui, B. N., Asif, F., Iqbal, S., Hassan, M. Z. Y., Malik, N. A., Najwa, M. S. (2002), “Impact of Loan Facilities Provided by PRSP for Poverty Alleviation in Farming Communities of Faisalabad." Journal of Applied Sciences, Vol. 2, No. 11, pp. 1002-1004.

Smith, A. (1976), An Inquiry into the Nature and Causes of The Wealth of Nations. 1937 Ed., p. 93. Retrieved from www.marxists.org/reference/.../smith-adam/works/.../index.htm

Socio-Economic Indicator of Bangladesh. (2007), Retrieved from mof.gov.bd/en/budget/ er/2007/ ksei. pdf?phpMyAdmin._

Stiglitz, J. E. (1990), "Peer Monitoring and Credit Markets." The World Bank Economic Review, Vol. 4, No. 3, 1990. pp. 351-66.

The Bangladesh Development Studies. (2004), Bangladesh Institute of Development Studies (BIDS).Volume XXX, Number 1\&2. Retrieved from http://www.bids.org.bd/Abstract01. php?FM=6\&SM=143.

The Role of Micro-Credit in Poverty Alleviation. (2009), "The Financial Express." Retrieved from http://www.thefinancialexpress-bd.com/2009/06/07/68933.html._

The Micro-credit Summit. (1997), "The Micro-Credit Summit: Declaration and Plan of Action." Washington, D.C. Retrieved from http://www.microcreditsummit.org/._

UNDP. (2007), "Human Development Index (HDI) of Bangladesh in UN Report." Retrieved from http:// bdoza.wordpress.com/2007/12/14/human-development-index-hdi-of-bangladesh-in-un-report/.

Varian, H. R. (1990), "Monitoring Agents with Other Agents." Journal of Institutional and Theoretical Economics, Vol. 146, 1990. pp. 153-174.

Westover, J. (2008), "The Record of Microfinance: The Effectiveness/Ineffectiveness of Microfinance Programs as a Means of Alleviating Poverty." Electronic Journal of Sociology. Retrieved from http://www.sociology.org/content/2008/_westover_finance.pdf.

World Bank. (2005), "Bangladesh PRSP Forum Economic Update: Recent Developments and Future Perspectives." Bangladesh Development Series, Paper No. 1, p. 25, World Bank Office, Dhaka.

World Savings Bank Institute. (2010), "Financial Service Access Can Accelerate Millennium Development Goals Achievement." Statement of 19 March. Retrieved from http://www.wsbi. org/uploadedFiles/Announcements/Millenium\%20Development\%20Goals\% 200p\%20Ed\%20 international\%20-\%20final\%20version.pdf. 